\title{
Dukungan Emosional Keluarga dan Teman Sebaya terhadap Self-Compassion pada Mahasiswa saat Pandemi COVID-19
}

\section{The Role of Family and Peer Emotional Support on Self-Compassion among Students during the COVID-19 Pandemic}

\author{
Pratista Arya Satwika ${ }^{1}$, Rini Setyowati ${ }^{1}$, Fika Anggawati ${ }^{2}$ \\ ${ }^{1}$ Program Studi Psikologi,Universitas Sebelas Maret, Surakarta, Indonesia \\ ${ }^{2}$ ADHD Center, Omah Lebah Kecil, Yogyakarta, Indonesia
}

\begin{abstract}
The purpose of this study was to determine the relationship between family and peer emotional support and self-compassion among the final year undergraduate students amid COVID-19 pandemic. A total number of 61 undergraduate students whose ages ranged from 19 to 26 years and who are completing their thesis at the time of this study were selected randomly. Data were collected using questionnaires of selfcompassion, and family and peer emotional support which were distributed online. The results of multiple linear regression analysis show that there is a significant relationship between emotional support from family and peers with self-compassion. However, when the analysis was conducted partially, only the relationship between family emotional support and self-compassion that is significant; while, the relationship between peer emotional support and self-compassion is not proved. It can be concluded from the results that there is a simultaneous relationship between family emotional support and peer emotional support with self-compassion owned by students who are completing their thesis during the COVID-19 pandemic.
\end{abstract}

Keywords: Emotional support, family, peer, self-compassion, students

\begin{abstract}
Abstrak: Penelitian ini bertujuan untuk menguji hubungan antara dukungan emosional keluarga dan teman sebaya dengan self-compassion pada mahasiswa tingkat akhir pada masa pandemic COVID-19. Sejumlah 61 mahasiswa yang sedang menyelesaikan tugas akhir dengan rentang usia 19 sampai 26 tahun direkrut menggunakan teknik random sampling. Data dikumpulkan menggunakan skala selfcompassion, dan dukungan emosional keluarga dan teman sebaya. Berdasarkan hasil analisis regresi linier berganda, diketahui bahwa terdapat hubungan yang signifikan antara dukungan emosional keluarga dan teman sebaya dengan self-compassion. Secara parsial, terdapat hubungan yang signifikan antara dukungan emosional keluarga dengan self-compassion, namun tidak terdapat hubungan antara dukungan emosional teman sebaya dengan self-compassion. Dapat disimpulkan bahwa terdapat hubungan secara simultan antara dukungan emosional keluarga dan dukungan emosional teman sebaya dengan self-compassion yang dimiliki oleh mahasiswa yang sedang menyelesaikan skripsi pada masa pandemi COVID-19.
\end{abstract}

Kata kunci: Dukungan emosional, keluarga, teman sebaya, self-compassion, mahasiswa

Korespondensi tentang artikel ini dapat dialamatkan kepada Pratista Arya Satwika melalui email pratista.arsat@gmail.com 
Karena penyebarannya yang cepat dan luas, Corona Virus Desease 2019 (COVID19) telah ditetapkan oleh World Health Organization (WHO) sebagai pandemi global sejak Maret 2020 (Kompas, 2020). Berdasarkan data terbaru dari World $o$ Meters pada 4 Mei 2021, jumlah kasus COVID-19 di dunia mencapai 154.177.380 kasus, dimana Amerika Serikat berada di posisi pertama, diikuti oleh India. Indonesia sendiri saat ini memiliki terkonfirmasi positif mencapai 1.682.004 kasus dengan penambahan kasus positif dalam 24 jam terakhir mencapai 4.730 orang dan masih menjadi negara tertinggi dengan kasus konfir-masi di Kawasan Asia Tenggara (Putra, 2021).

Indonesia yang merupakan salah satu negara terdampak virus COVID-19, mengambil beberapa langkah pencegahan penyebaran virus tersebut, di antaranya melalui program Pembatasan Sosial Berskala Besar (PSBB) yang telah diterapkan sejak tanggal 10 April 2020 lewat PP No 21 tahun 2020. Pembatasan tersebut dilakukan dengan meminimalkan peliburan sekolah dan tempat kerja, pembatasan kegiatan keagamaan dan pembatasan kegiatan di tempat atau fasilitas umum. Namun, pembatasan tersebut tetap mempertimbangkan kebutuhan pendidikan, produktivitas kerja, dan ibadah serta pemenuhan atas kebutuhan dasar dari penduduk (Kementerian Koordinator Bidang Pembangunan Manusia dan Kebudayaan Republik Indonesia, 2020)

Sebagai konsekuensi dari PSBB, pemerintah mengeluarkan kebijakan berupa belajar dari rumah, bekerja dari rumah, dan beribadah dari rumah. Pada bidang pendidikan, proses pembelajaran yang biasanya dilakukan secara tatap muka, kini dialihkan menjadi sistem pembelajaran jarak jauh atau dalam jaringan (daring) dari rumah siswa masing-masing melalui sarana teknologi komunikasi berbasis internet.

Perubahan proses pembelajaran menjadi secara daring ini juga dirasakan oleh mahasiswa di perguruan tinggi. Seiring dengan upaya pencegahan penyebaran virus COVID-19 di lingkungan kampus, banyak perguruan tinggi menutup kampusnya kecuali hanya untuk kegiatan khusus yang tak dapat dilakukan secara jarak jauh. Penutupan kampus ini secara tidak langsung juga membatasi akses terhadap sumber belajar yang dibutuhkan guna mendukung proses pembelajaran seperti perpustakaan. Perubahan proses pembelajaran ini menjadi masalah tersendiri bagi mahasiswa karena hambatan dalam mendapatkan akses belajar maupun bimbingan belajar dari para dosen. Pada situasi ini, mahasiswa dapat mengalami kebingungan, menjadi pasif, dan kurang produktif (Argaheni, 2020). Kondisi semacam ini dapat menyebabkan munculnya stres akademik pada mahasiswa (Andiarna \& Kusumawati, 2020; Argaheni, 2020; Nurmala et al., 2020).

Masa penyelesaian tugas akhir atau skripsi merupakan fase yang riskan bagi sebagian besar mahasiswa tingkat akhir. Aktivitas akademik ini tidak jarang menjadi sumber stres pada mahasiswa (Budiman \& Ardianty, 2018; Gamayanti et al., 2018). Keberadaan pandemi dan segala perubahannya dapat menjadi penyebab stres tambahan bagi mahasiswa tingkat akhir. Oleh sebab itu. penelitian ini difokuskan pada salah satu fase akademik yang harus dilalui oleh mahasiswa yaitu masa penyelesaian skripsi.

Secara global, kesehatan mental mahasiswa selama pandemi, menurut Zalaznick (2020), adalah banyak yang mengalami stres atau kecemasan $(91 \%)$, merasa kecewa atau sedih $(81 \%)$, dan merasa kesepian atau terisolasi (80\%). Terdapat juga mahasiswa yang mengalami persoalan keuangan (48\%) dan juga mengalami relokasi (56\%). Lee et al. (2021) juga melaporkan bahwa sekitar $88 \%$ siswa mengalami stres sedang hingga berat, $44 \%$ mahasiswa yang menunjukkan kecemasan sedang hingga berat, serta $36 \%$ mahasiswa mengalami depresi sedang hingga berat.

Khusus pada mahasiswa yang berada pada masa penyelesaian skripsi, Fauziah dan Jamaliah (2021) menemukan bahwa terdapat beberapa macam kesulitan yang dihadapi mereka selama pandemi COVID- 
19, baik secara akademik maupun nonakademik. Kesulitan akademik disebabkan oleh tantangan menyesuaikan topik penelitian dengan situasi terkini, kurang memahami metode penelitian dan gaya tulisan akademik. Pada bidang nonakademik, kesulitan mahasiswa didominasi oleh kesiapan pribadi.

Nurcahyo dan Valentina, (2020) juga menemukan bahwa sumber stres mahasiswa dalam menyusun skripsi salah satunya adalah situasi pandemi yang terjadi. Terdapat tema 'kekhawatiran diri' yang muncul dari analisis kualitatif yang mereka lakukan terhadap mahasiswa yang sedang menyusun skripsi. Tema tersebut menunjukkan bahwa muncul perasaan cemas, takut serta bingung pada mahasiswa tentang apa yang harus dilakukannya dalam mengerjakan skripsi pada kondisi pandemi ini. Kondisi ini membuat penyelesaian skripsi menjadi berbeda dengan apa yang pernah mereka lihat dari kakak tingkatnya sebelum masa pandemi (Nurcahyo \& Valentina, 2020).

Beberapa penelitian tersebut menunjukkan adanya beberapa gejala stres yang di alami oleh mahasiswa dalam penyelesaian skripsinya, sebagaimana temuan penelitian Gamayanti et al. (2018), yaitu cepat merasa lelah, tidak bersemangat, menunda nunda penyelesaian skripsi, melupakan dan menghindari dosen pembimbing serta memiliki keinginan untuk berhenti mengerjakan skripsi. Padahal dalam proses penyelesaian skripsi. Selain proses bimbingan dan pengerjaan skripsi, terdapat proses ujian pertanggungjawaban karya ilmiah yang dapat menjadi sumber stres lain. Bagi mahasiswa, ujian skripsi dapat menjadi peristiwa yang menimbulkan kecemasan (Budiman \& Ardianty, 2018). Kondisi perasaan, pikiran dan perilaku motorik yang tidak terkendali dapat memicu munculnya kecemasan. Hal ini membuat pikiran menjadi tegang, muncul perasaan akan terjadi hal yang buruk hingga menyebabkan mahasiswa yang menghadapi ujian khususnya ujian skripsi menjadi gugup (Maisaroh \& Falah, 2011).
Pada situasi ini, dibutuhkan adanya keterampilan yang dapat membantu mahasiswa dalam menghadapi emosi-emosi negatif yang mereka rasakan. Self-compassion atau sikap belas kasih diri membuat individu mampu untuk melakukan pengaturan emosi adaptif yang dicirikan oleh kebaikan terhadap diri sendiri, kemanusiaan umum dan perhatian. Adanya self-compassion dapat membuat individu mampu menerima segala situasi yang terjadi baik itu permasalahan maupun kekurangan yang terjadi padanya. Menurut Germer (dalam Muttaqin et al., 2020), berbeda dengan penerimaan pada umumnya yang mengarahkan pada menerima apa yang terjadi seperti menerima perasaan atau pikiran, self-compassion sedikit berbeda karena lebih mengarahkan individu untuk dapat tetap menerima dirinya walaupun sedang menghadapi penderitaan atau peristiwa yang negatif.

Self-compassion juga merupakan kemampuan individu untuk melihat pengalaman personal sebagai suatu hal yang manusiawi, dan menyadari perasaan yang hadir tanpa melakukan identifikasi yang berlebihan (Neff, 2004). Individu dengan selfcompassion memiliki kebaikan dan pemahaman terhadap diri, sehingga dapat menerima kekurangan dalam diri dan tidak memberikan penghakiman saat mengalami kegagalan. Dalam menghadapi peristiwa hidup yang negatif, self-compassion karena itu dapat menjadi sumber internal yang berharga (Allen \& Leary, 2013).

Terdapat tiga komponen dasar yang membentuk self-compassion, yaitu: selfkindness, common humanity, dan mindfulness. Self-kindness adalah kemampuan untuk menciptakan kenyamanan pada diri sendiri ketika merasakan sakit dan membutuhkan perhatian. Common humanity merupakan pemahaman bahwa tantangan hidup dan kegagalan pribadi merupakan hal yang manusiawi. Sementara mindfulness merupakan kondisi dimana seseorang menyadari pengalaman yang sedang terjadi secara jelas dan berperilaku dengan ketenangan jiwa (Muttaqin et al., 2020; Neff, 2015; 
Neff \& Seppala, 2016; Neff \& Davidson, 2016).

Saat menemui hambatan dalam mengerjakan skripsi, mahasiswa dengan selfcompassion yang tinggi akan tetap mampu menerima dan menghargai dirinya (Siswati \& Hadiyati, 2017); serta mampu bangkit kembali dan beradaptasi dengan keadaannya yang sulit (Hatari \& Setyawan, 2018). Sementara itu, mahasiswa dalam proses kehidupannya secara sosial akan banyak berinteraksi dengan orang tua dan teman sebayanya. Neff (2003) mengemukakan bahwa faktor lingkungan mempengaruhi pertumbuhan self-compassion pada diri individu. Self-compassion yang dimiliki individu dapat berkembang dengan dukungan dari ibu, ayah dan teman sebaya (Neff \& McGehee, 2010). Hubungan yang suportif dan hangat dengan orang tua serta pemahaman bahwa dirinya dimengerti dan disayangi oleh orang tua akan meningkatkan self-compassion pada individu (Neff, 2003).

Kondisi pandemi juga menjadikan lingkungan keluarga menjadi faktor pendorong yang memotivasi bagi mahasiswa untuk dapat menyelesaikan skripsi, karena pembatasan sosial menjadikan mahasiswa lebih banyak menyusun skripsi di tengah ke-luarga (Nurcahyo \& Valentina, 2020).

Beberapa penelitian menemukan bahwa self-compassion dapat tumbuh dengan adanya dukungan positif dari keluarga (Nafisah et al., 2018). Sementara sikap penolakan orang tua, sikap proteksi yang berlebihan dan rendahnya kehangatan yang diterima pada masa kanak-kanak memprediksikan rendahnya tingkat self-compassion (Pepping et al., 2015). Selain keterikatan dalam keluarga, keterhubungan secara sosial menjadi salah satu faktor juga yang mempengaruhi self-compassion (Ying \& Hashim, 2016).

Mahasiswa dalam kehidupan sosialnya lebih banyak berinteraksi dengan orang tua dan teman sebayanya, hal tersebut memicu ketertarikan peneliti untuk menguji adanya hubungan antara dukungan emosional keluarga dan teman sebaya terhadap self- compassion mahasiswa yang sedang menyelesaikan skripsi pada masa pandemi COVID-19.

Hipotesis penelitian yang diajukan dalam penelitian ini adalah:

H1: Ada hubungan antara dukungan emosional keluarga dan dukungan emosional teman sebaya dengan self-compassion.

$\mathrm{H} 2$ : Ada hubungan antara dukungan emosional keluarga dengan selfcompassion.

H3: Ada hubungan antara dukungan emosional teman sebaya dengan self-compassion.

\section{Metode}

Sampel

Penelitian ini menggunakan subjek berjumlah 61 mahasiswa Prodi Psikologi Fakultas Kedokteran Universitas Sebelas Maret yang sedang menyelesaikan skripsi. Subjek terdiri dari 8 laki laki dan 53 perempuan dengan rentang usia 19 sampai 26 tahun. Peneliti menggunakan google form untuk membantu penyebaran skala di setiap angkatan yang sedang dalam proses pengerjaan skripsi. Penyebaran skala di lakukan mulai dari tanggal 30 Juni 2020 sampai 7 September 2020 dengan pengambilan data menggunakan teknik random sampling.

Mayoritas subjek penelitian adalah mahasiswa angkatan 2016 (57,38\%) dan yang lainnya merupakan mahasiswa angkatan 2017 (13,11\%), angkatan 2015 (14,75\%), angkatan 2014 (4,9\%) dan angkatan 2013 $(9,8 \%)$.

\section{Pengumpulan Data}

Data dikumpulkan menggunakan tiga alat ukur. Variabel self-compassion diukur menggunakan skala self-compassion yang disusun berdasarkan teori Neff (2015). Selfcompassion terdiri dari 3 dimensi yaitu selfkindness, common humanity dan mindfulness. Skala tersebut terdiri dari 23 aitem dengan reliabilitas alpha Cronbach sebesar 0,914 dan indeks daya beda aitem berkisar 
antara 0,385 sampai 0,746 .

Variabel dukungan emosional keluarga diukur menggunakan skala dukungan emosional keluarga yang disusun berdasarkan teori Sarafino dan Smith (2011). Dukungan emosional keluarga terdiri dari 4 dimensi yaitu rasa empati, peduli, perhatian positif dan kepercayaan. Skala ini berjumlah 8 aitem dengan reliabilitas alpha Cronbach sebesar 0,832 dan indeks daya beda aitem berkisar antara 0,431 sampai 0,687 .

Variabel dukungan emosional teman sebaya di ukur dengan menggunakan skala emosional teman sebaya yang disusun berdasarkan teori dari Sarafino dan Smith (2011). Dukungan emosional teman sebaya terdiri dari 4 aspek yaitu rasa empati, peduli, perhatian positif dan kepercayaan. Terdapat 8 aitem dalam skala ini dengan reliabilitas alpha Cronbach sebesar 0,855 dan indeks daya beda aitem berkisar antara 0,393 sampai 0,803 .

\section{Analisis Data}

Data penelitian dianalisis dengan bantuan program IBM SPSS Statistics 23 for windows menggunakan uji regresi linear berganda. Sebelum dilakukan uji hipotesis, uji asumsi telah dilakukan. Data dalam penelitian ini terdistribusi secara normal ( $>0,05$ ) dan menunjukkan bahwa variabel dukungan emosional keluarga dan selfcompassion berhubungan secara linear $(\mathrm{p}<0,05)$. Hubungan linear juga terjadi pada variabel dukungan emosional teman sebaya dengan self-compassion pada mahasiswa yang sedang menyelesaikan skripsi saat pandemi COVID-19.

\section{Hasil}

Hasil analisis statistik deskriptif data penelitian diketahui bahwa dari 61 subjek penelitian didapatkan rerata empirik variabel dukungan emosional keluarga sebesar 26,98, dukungan emosional teman sebaya sebesar 31,05 dan self-compassion sebesar 72,82 (lihat Tabel 1).

Tabel 1. Statistik Deskriptif

\begin{tabular}{lccc}
\hline & $\mathrm{N}$ & Mean & SD \\
\hline $\begin{array}{l}\text { Dukungan emosional } \\
\text { keluarga }\end{array}$ & 61 & 26.9836 & 6.02354 \\
$\begin{array}{l}\text { Dukungan emosional } \\
\text { teman sebaya }\end{array}$ & 61 & 31.0492 & 4.42503 \\
Self-compassion & 61 & 72.8197 & 13.55914 \\
\hline
\end{tabular}

Hasil uji hipotesis pertama menunjukkan bahwa hipotesis pertama dapat diterima (lihat Tabel 2), terdapat peran yang signifikan dari dukungan emosional keluarga dan teman sebaya pada self-compassion pada mahasiswa yang menyelesaikan skripsi pada pandemi COVID-19 $\left(\mathrm{R}=560 ; \mathrm{R}^{2}\right.$ $=0,313 ; F_{\text {hitung }}=13,236>F_{\text {tabel }}=3,16$; $\mathrm{p}<0,05$ ) (lihat Tabel 2 dan 3). Berdasarkan analisis yang dilakukan self-compassion mahasiswa yang sedang mengerjakan skripsi saat pandemi COVID-19 dapat dijelaskan oleh dukungan emosional keluarga dan dukungan emosional teman sebaya sebesar $31,3 \%$ sisanya yaitu $68,7 \%$ dijelaskan oleh faktor lain di luar penelitian.

Tabel 2. Hasil Uji Hipotesis Model Summary

\begin{tabular}{ccccc}
\hline Model & R & R Square & Adjusted R Square & Std. Error of the Estimate \\
\hline 1 & $.560^{\mathrm{a}}$ & .313 & .290 & 11.42755 \\
\hline
\end{tabular}

Tabel 3. Hasil Uji Hipotesis Anova

\begin{tabular}{llccccc}
\hline \multicolumn{1}{l}{ Model } & Sum of Squares & Df & Mean Square & F & Sig. \\
\hline \multirow{3}{*}{1} & Regression & 3456.865 & 2 & 1728.432 & 13.236 & $.000^{\mathrm{b}}$ \\
\cline { 2 - 7 } & Residual & 7574.152 & 58 & 130.589 & & \\
\cline { 2 - 8 } & Total & 11031.016 & 60 & & & \\
\hline
\end{tabular}


Tabel 4. Hasil Uji Hipotesis Coefficients

\begin{tabular}{lccccccccc}
\hline \multirow{2}{*}{ Model } & \multicolumn{2}{c}{$\begin{array}{c}\text { Unstandardized } \\
\text { Coefficients }\end{array}$} & $\begin{array}{c}\text { Standardized } \\
\text { Coefficients }\end{array}$ & $\mathrm{t}$ & \multicolumn{2}{c}{ Sig. } & \multicolumn{2}{c}{ Correlations } \\
\cline { 2 - 9 } & $\mathrm{B}$ & Std. Error & Beta & & & $\begin{array}{c}\text { Zero- } \\
\text { order }\end{array}$ & Partial & Part \\
\hline $\begin{array}{l}\text { (Constant) } \\
\text { Dukungan }\end{array}$ & 28.373 & 11.425 & & 2.484 & .016 & & & \\
$\begin{array}{l}\text { emosional } \\
\text { keluarga }\end{array}$ & 1.160 & .250 & .515 & 4.637 & .000 & .543 & .520 & .504 \\
$\begin{array}{l}\text { Dukungan } \\
\text { emosional } \\
\text { teman sebaya }\end{array}$ & .424 & .340 & .138 & 1.244 & .218 & .243 & .161 & .135 \\
\hline
\end{tabular}

a. Dependent Variable: Self-compassion

Berdasarkan hasil tersebut didapati bahwa baik dukungan emosional yang di berikan oleh keluarga maupun dukungan emosional yang di berikan oleh teman sebaya masing masing memiliki peran dalam meningkatkan self-compassion mahasiswa yang menyelesaikan skripsi pada pandemi COVID-19.

Peneliti juga merumuskan model persamaan regresi pada penelitian ini, yaitu Self-compassion $=28,373+1,160$, dukungan emosional keluarga $+0,424$, dukungan emosional teman sebaya. Koefisien tersebut bernilai positif.

Hasil uji hipotesis kedua secara parsial ditemukan bahwa dukungan emosional keluarga memiliki hubungan yang signifikan dengan self-compassion ( $\mathrm{t}_{\text {hitung }}=4,637$ $\left.>\mathrm{t}_{\text {tabel }}=2,000 ; p<0,05\right)$ (lihat Tabel 4). Dapat disimpulkan bahwa hipotesis kedua juga di terima.

Sementara itu, hal uji hipotesis ketiga dengan korelasi parsial menunjukkan bahwa dukungan emosional teman sebaya tidak memiliki hubungan yang signifikan dengan self-compassion $\left(\mathrm{t}_{\text {hitung }}=1,244<\mathrm{t}_{\text {tabel }}=\right.$ 2,000; $p>0,05$ ) (Lihat Tabel 4), sehingga dapat di simpulkan bahwa hipotesis ketiga tidak diterima.

\section{Pembahasan}

Berdasarkan hasil analisis data hasil penelitian ini, nilai signifikansi yang diperoleh membuktikan bahwa hipotesis per- tama (H1) diterima. Artinya dukungan emosional keluarga dan teman sebaya terbukti berhubungan signifikan dengan selfcompassion pada mahasiswa yang sedang menyelesaikan skripsi pada saat pandemi COVID-19. Semakin tinggi dukungan emosional keluarga dan dukungan emosional teman sebaya yang di rasakan maka akan semakin tinggi pula self-compassion mahasiswa yang sedang menyelesaikan skripsi pada masa pandemi.

Hasil penelitian ini selaras dengan wawasan teoretis yang mendasari penelitian ini bahwa dukungan emosional keluarga dan dukungan emosional teman sebaya berhubungan dengan self-compassion mahasiswa. Dukungan emosional keluarga dan teman sebaya berperan sebagai faktor lingkungan yang dapat mengembangkan selfcompassion (Neff, 2003; Neff \& McGehee, 2010), terutama pada mahasiswa yang sedang menyelesaikan skripsi pada masa pandemi.

Fase penyelesaian skripsi dan masa pandemi COVID-19 membuat mahasiswa mendapatkan tantangan yang lebih berat karena akibat dari perubahan yang terjadi. 'Kekhawatiran diri' yang di rasakan oleh mahasiswa dalam menyusun skripsi pada masa pandemi COVID-19 ini akan menjadi suatu ancaman yang dapat menimbulkan stres (Nurcahyo \& Valentina, 2020).

Hubungan hangat dan suportif yang di rasakan oleh individu dari keluarga dan teman sebayanya seperti rasa empati, 
peduli, perhatian positif serta kepercayaan akan meningkatkan kemampuan individu dalam memahami dirinya sendiri. Karena itu, ketika menghadapi situasi kegagalan, individu akan dapat menerima kekurangan dalam dirinya dan tidak memberikan penghakiman terhadap dirinya sendiri (Neff, 2003).

Hasil uji hipotesis kedua dengan korelasi parsial di dapatkan hasil yang signifikan hubungan antara dukungan emosional keluarga dengan self-compassion pada mahasiswa yang sedang mengerjakan skripsi saat pandemi COVID-19. Hasil signifikan ini sesuai dengan penelitian sebelumnya dari Pepping et al. (2015) yang menemukan bahwa sikap proteksi berlebihan dan sikap penolakan orang tua, rendahnya kehangatan yang diterima pada masa kanak-kanak dapat memprediksi rendahnya tingkat selfcompassion individu. Nafisah et al. (2018) juga menemukan adanya keterkaitan yang positif antara dukungan keluarga dengan self-compassion pada remaja.

Neff dan McGehee (2010) menambahkan bahwa keberfungsian keluarga menjadi prediktor yang kuat dalam membentuk self-compassion individu. Individu yang berasal dari keluarga yang harmonis, orang tua yang memberikan kehangatan, kepedulian, dukungan dan mengajarkan penyelesaian dengan cara dialog akan membentuk tingkat self-compassion yang tinggi. Sementara keluarga yang dingin, pemarah, sering memberikan kritik kepada anak mereka akan mengakibatkan tingkat selfcompassion yang rendah. Eker dan Kaya (2018) juga menemukan bahwa siswa yang mempersepsikan sikap orang tuanya demokratis cenderung memiliki self-compassion yang tinggi, sementara siswa yang menganggap orang tuanya otoriter cenderung memiliki self-compassion yang rendah.

Hasil uji hipotesis ketiga menggunakan analisis korelasi parsial menunjukkan bahwa tidak terdapat hubungan yang signifikan antara dukungan emosional teman sebaya dengan self-compassion mahasiswa yang sedang menyelesaikan skripsi. Mahasiswa sesuai dengan perkembangannya mengalami beberapa perubahan salah satunya adalah kemampuan berpikir yang juga meningkatkan kemampuan introspeksi diri, metakognisi, refleksi diri dan kemampuan pengambilan perspektif sosial dan juga beberapa tanggung jawab (Neff, 2003). Kemampuan tersebut membuat mahasiswa secara terus menerus mengevaluasi diri mereka sendiri dan membandingkan diri mereka dengan orang lain untuk membentuk identitasnya (Neff, 2003).

Pada fase ini, teman sebaya menjadi tujuan pembandingan tersebut. Namun, hal ini ternyata tidak serta merta dapat memberikan pengaruh kepada kemampuan mahasiswa dalam memahami dirinya sendiri, terutama dalam menerima kekurangan yang dimilikinya karena kebanyakan teman sebaya juga mengalami masalah yang sama terutama pada situasi pandemi COVID-19. Pada situasi pandemi COVID-19 ini membuat para mahasiswa lebih banyak menyusun skripsi di tengah keluarga sehingga dukungan keluarga lebih memotivasi mahasiswa dalam mengembangkan selfcompassionnya.

Jika dilihat dari sebaran kategorisasi penelitian yang telah di lakukan secara keseluruhan, mahasiswa yang sedang menyelesaikan skripsi di masa pandemi COVID19 ini memiliki self-compassion yang sedang, dukungan emosional keluarga yang sedang, serta dukungan emosional teman sebaya yang tinggi (lihat Tabel 1). Namun, dukungan emosional teman sebaya yang tinggi diterima oleh mahasiswa ternyata tidak serta merta mempengaruhi bagaimana mahasiswa untuk berbelas kasih pada dirinya sendiri terutama jika tidak didukung oleh dukungan emosional dari keluarga.

Nafisah et al. (2018) menemukan bahwa keluarga merupakan tempat seorang anak bergantung dari awal kehidupannya, sehingga persepsi mahasiswa bahwa dirinya dipedulikan, dipercayai, serta diberikan perhatian positif dari keluarga membantu mahasiswa dalam menghadapi hal hal yang menakutkan dan merasa aman terutama 
ketika di hadapkan pada situasi yang menjadi sumber stres seperti penyelesaian tugas akhir. Apalagi penyelesaian skripsi tersebut dilakukan pada masa pandemi COVID-19, dimana adanya Pembatasan Sosial Berskala Besar yang menjadikan mahasiswa lebih banyak berada di lingkungan keluarga.

Dukungan emosional yang diperoleh dari keluarga menjadi kunci utama mahasiswa dalam mengembangkan kemampuannya untuk menghentikan sikap menghakimi diri sendiri ketika menghadapi kegagalan (self-kindness), memberikan kesadaran bahwa semua manusia dapat melakukan kesalahan dan tidak sempurna (common humanity) serta sikap sadar untuk menerima dan memberikan toleransi terhadap kesalahan yang terjadi (mindfulness).

Muttaqin et al. (2020) juga menyimpulkan bahwa kepuasan hidup akan dapat dicapai oleh individu yang memiliki selfcompassion yang tinggi dibandingkan dengan individu yang kurang memiliki selfcompassion .

\section{Simpulan}

Penelitian ini telah membuktikan bahwa terdapat hubungan signifikan antara dukungan emosional keluarga dan dukungan emosional teman sebaya secara simultan dengan self-compassion pada mahasiswa yang sedang menyelesaikan skripsi di masa pandemi COVID-19. Selain itu, juga dapat dibuktikan adanya hubungan parsial antara dukungan emosional keluarga dengan selfcompassion mahasiswa tersebut. Namun, hubungan antara dukungan emosional dari teman sebaya dengan self-compassion pada mahasiswa yang sedang menyelesaikan skripsi di masa pandemi COVID-19 secara parsial tidak terbukti.

\section{Saran}

Hasil penelitian ini diharapkan dapat menjadi masukan bagi pihak yang berkepentingan seperti orang tua, pihak universitas dan mahasiswa itu sendiri dalam mendorong peningkatan self-compassion mahasiswa yang sedang menyelesaikan skripsi terutama ketika situasi kurang mendukung seperti saat pandemi COVID-19 dengan cara meningkatkan dukungan emosional pada mereka.

Dukungan emosional keluarga dapat meningkatkan kemampuan mahasiswa untuk lebih peduli terhadap dirinya sendiri sebagaimana dirinya memperlakukan orang lain yang disayangi. Dengan demikian, keluarga dapat lebih meningkatkan kepedulian, kepercayaan, rasa empati dan perhatian yang positif terhadap mahasiswa agar mereka dapat mengembangkan kualitas dari self-compassion secara optimal terutama ketika berada pada tahap penyelesaian skripsi pada saat pandemi COVID-19 saat ini.

\section{Acknowledgement}

Artikel ini ditulis berdasarkan hasil penelitian yang dibiayai oleh Universitas Negeri Sebelas Maret, Surakarta, melalui skema dana PNBP tahun 2020.

\section{Daftar Pustaka}

Allen, A. B., \& Leary, M. R. (2013). Selfcompassionate responses to aging. Gerontologist, 54(2) 1-11. https://doi.org/10.1093/geront/gns2 04

Andiarna, F., \& Kusumawati, E. (2020).
Effects of Online Learning on Student Academic Stress During the Covid-19 Pandemic. Jurnal Psikologi, 16(2), 139150.

https://doi.org/http://dx.doi.org/10.24014 / jp.v14i2.9221 
Argaheni, N. B. (2020). Sistematik Review: Dampak Perkuliahan Daring Saat Pandemi COVID-19 Terhadap Mahasiswa Indonesia. PLACENTUM: Jurnal Ilmiah Kesehatan Dan Aplikasinya, 8(2), 99-108.

https://doi.org/10.20961/placentum .v8i2.43008

Budiman, \& Ardianty, S. (2018). Pengaruh Efektivitas Terapi Self Healing Menggunakan Energi Reiki terhadap Kecemasan Menghadapi Ujian Skripsi. Psympathic: Jurnal Ilmiah Psikologi, 4(1), 141-148. https://doi.org/10.15575/psy.v4i1.1 227

Eker, H., \& Kaya, M. (2018). Examining University Students' SelfCompassion and Compassionate Love Levels in Terms of Perceived Parental Attitudes. Journal of Education and Training Studies, 6(11), 49-56. https://doi.org/10.11114/jets.v6i11. 3407

Fauziah, \& Jamaliah. (2021). Analisis Kesulitan Mahasiswa Menyelesaikan Skripsi di Masa Pandemi Pada Prodi Pendidikan Bahasa Inggris. Proceeding Seminar Nasional Multidisiplin Ilmu, 1(1), 9-14. Lembaga Penelitian Dan Pengabdian Kepada Masyarakat (LPPM) Universitas Jabal Ghafur. https://doi.org/http://journal.unigha .ac.id/index.php/SemNas

Gamayanti, W., Mahardianisa, M., \& Syafei, I. (2018). Self Disclosure dan Tingkat Stres pada Mahasiswa yang sedang Mengerjakan Skripsi. Psympathic: Jurnal Ilmiah Psikologi, 5(1), 115-130. https://doi.org/10.15575/psy.v5i1.2 282
Hatari, S., \& Setyawan, I. (2018). Hubungan Antara Self Compassion dengan Resiliensi pada Mahasiswa yang Sedang Mengerjakan Skripsi di Fakultas Psikologi Universitas Diponegoro. Empati, 7(1), 54-59. https://ejournal3.undip.ac.id/index. php/empati/article/view/20146

Kementerian Koordinator Bidang Pembangunan Manusia dan Kebudayaan Republik Indonesia. (2020). Pembatasan Sosial Berskala Besar. https://www.kemenkopmk.go.id/pe mbatasan-sosial-berskala-besar

Kompas. (2020, 20 Maret). WHO Tetapkan Wabah Virus Corona Sebagai Pandemi Global. https://www.kompas.tv/article/708 93/who-tetapkan-wabah-viruscorona-sebagai-pandemi-global

Lee, J., Jeong, J. H., \& Kim, S. (2021). Stress, Anxiety, and Depression Among Undergraduate Students during the COVID-19 Pandemic and their Use of Mental Health Services. Innovative Higher Education, $\quad 0123456789$. https://doi.org/10.1007/s10755021-09552-y

Maisaroh, E. N., \& Falah, F. (2011). Religiusitas Dan Kecemasan Menghadapi Ujian Nasional (UN) Pada Siswa Madrasah Aliyah. Proyeksi, 6(2), 78-88. https://doi.org/10.30659/p.6.2.7888

Muttaqin, D., Yunanto, T. A. R., Fitria, A. Z. N., Ramadhanty, A. M., \& Lempang, G. F. (2020). Properti psikometri Self-Compassion Scale versi Indonesia: Struktur faktor, reliabilitas, dan validitas kriteria. Persona:Jurnal Psikologi Indonesia, 9(2), 189-208. https://doi.org/10.30996/persona.v 9i2.3944 
Nafisah, A., Hendriyani, R., \& Martiarini, N. (2018). Hubungan antara Dukungan Keluarga dengan Self Compassion Remaja di Panti Asuhan. Intuisi Jurnal Psikologi Ilmiah, 10(2), 160-166. https://doi.org/10.15294/intuisi.v10 i2. 17494

Neff, K. (2003). Self-Compassion: An Alternative Conceptualization of a Healthy Attitude Toward Oneself. Self and Identity, 2, 85-101. https://doi.org/10.1016/s07618425(04)71291-7

Neff, K. (2004). Self Compassion and Psychological Well-Being. Constructivism in the Human Sciences, 9(2), 27-37. http://selfcompassion.org/wpcontent/uploads/publications/Selfcompassion\%20and\%20Wellbeing.pdf

Neff, K. D. (2015). The Self-Compassion Scale is a Valid and Theoretically Coherent Measure of SelfCompassion. Mindfulness, 7(1), 264-274.

https://doi.org/10.1007/s12671015-0479-3

Neff, K. D., \& McGehee, P. (2010). Selfcompassion and psychological resilience among adolescents and young adults. Self and Identity, 9(3), 225-240. https://doi.org/10.1080/152988609 02979307

Neff, K. D., \& Seppala, E. (2016). Compassion, Well-Being, and the Hypoegoic Self. In K. W. Brown \& M. R. Leary (Eds.), Oxford Handbook of Hypo-egoic Phenomena: Theory and Research on the Quiet Ego (pp. 189-204). Oxford University Press. https://doi.org/10.1093/oxfordhb/9 780199328079.013 .13
Neff, K., \& Davidson, O. (2016). Selfcompassion: Embracing suffering with kindness. In I. Ivtzan \& $\mathrm{T}$. Lomas (Eds.), Mindfulness in positive psychology: The science of meditation and wellbeing (pp. 3750). Routledge/Taylor \& Francis Group.

https://doi.org/10.4324/978131574 7217

Nurcahyo, F. A., \& Valentina, T. D. (2020). Menyusun Skripsi di Masa Pandemi? Studi Kualitatif Kesejahteraan Psikologis. Prosiding Seminar Nasional aan Call Paper "Psikologi Positif Menuju Mental Wellness," 136144.

http://conference.um.ac.id/index.ph $\mathrm{p} / \mathrm{psi} /$ article/view/26

Nurmala, M. D., Wibowo, T. U. S. H., \& Rachmayani, A. (2020). Tingkat Stres Mahasiswa Dalam Pembelajaran Online Pada Masa Pandemi Covid-19. Jurnal Penelitian Bimbingan dan Konseling, 5(2), 13-23. https://doi.org/http://dx.doi.org/10. 30870/jpbk.v5i2.10108

Pepping, C. A., Davis, P. J., O’Donovan, A., \& Pal, J. (2015). Individual Differences in Self-Compassion: The Role of Attachment and Experiences of Parenting in Childhood. Self and Identity, 14(1), 104-117. https://doi.org/10.1080/15298868.2 014.955050

Putra, B. M. (2021, Mei 4). Update Covid-19 Dunia 4 Mei 2021_Kasus Konfirmasi Indonesia Tertinggi di Asia Tenggara - Pikiran-Rakyat. https://www.pikiranrakyat.com/internasional/pr011866344/update-covid-19-dunia4-mei-2021-kasus-konfirmasiindonesia-tertinggi-di-asiatenggara 
Sarafino, E. P., \& Smith, T. W. (2011). Health

Psychology:

Biopsychosocial Interactions $\left(^{\text {th }}\right.$ ed.). John Wiley \& Sons, Inc.

Siswati, S., \& Hadiyati, F. N. R. (2017). Hubungan Antara Self-Compassion dan Efikasi Diri pada Mahasiswa yang Sedang Menyelesaikan Tugas Akhir. Mediapsi, 03(02), 22-28. https://doi.org/10.21776/ub.mps.20 17.003.02.3

Ying, K., \& Hashim, I. H. M. (2016). Self-Compassion , Social Connectedness and Self-Regulation of Health Behaviour: A
Preliminary Study on Local Undergraduates in Malaysia. 3rd Kanita Postgraduate International Conference on Gender Studies, November, 240-252. https://www.researchgate.net/publi cation/332143289

Zalaznick, M. (2020). Student mental health has 'significantly worsened' during pandemic. https://universitybusiness.com/men tal-health-college-studentwellness-telehealth-teletherapyactive-minds/ 